\title{
Review \\ Review of Effects of Dam Construction on the Ecosystems of River Estuary and Nearby Marine Areas
}

\author{
Xuan Zhang ${ }^{1}$, Changling Fang ${ }^{1}$, Yuan Wang ${ }^{1}$, Xiaoyi Lou ${ }^{1}$, Ying Su ${ }^{2, *}$ and Dongmei Huang 1,* \\ 1 Ministry of Agriculture and Rural Affairs, East China Sea Fisheries Research Institute, Chinese Academy of \\ Fishery Sciences, Shanghai 200090, China; zhangxuan@ecsf.ac.cn (X.Z.); fangling034081@163.com (C.F.); \\ wangyuan8@163.com (Y.W.); huoxingmayi@126.com (X.L.) \\ 2 College of Ocean Science and Technology, Dalian University of Technology, Dalian, Liaoning, 116024, \\ China \\ * Correspondence: yingsu@dlut.edu.cn (Y.S.); hdm2001@126.com (D.H.)
}

\begin{abstract}
Dams have made great contributions to human society, facilitating flood control, power generation, shipping, agriculture and industry. However, the construction of dams greatly impacts downstream ecological environments and nearby marine areas. To summarize these impacts, this review used recent research to comprehensively analyze how dam construction has affected river hydrology, geomorphology, and ecosystem of downstream reaches globally. Effects of dams on ecosystems occur through reduced river flow, reduced sediment flux, altered water temperature, changed estuary delta, altered composition and distribution of nutrients, altered structure and distribution of phytoplankton populations, caused habitat fragmentation, and blocked migration routes in river sections and adjacent seas. Besides, exploring new reservoir management strategies (including targeted control of dam storage and flushing sediment operations), banning fishing activities, and removing unnecessary dams (obsolete or small dams) are becoming crucial tools for ecosystem restoration.
\end{abstract}

Keywords: Dam; River estuary; Ecosystem; Effect

\section{Introduction}

Dam construction has a long history, especially in China where dams have been utilized since 3000 BC. People build dams mainly for river control, flood control, irrigation, hydropower, and shipping. According to statistics from the International Commission on Large Dams, as of April 2020 there were 68,000 large dams with heights of over $15 \mathrm{~m}$ or impounding more than 3 million $\mathrm{m} 3$ in the world (38,000 of which were located in China) (Figure 1) [1,2]. The total storage capacity of these dams approached $8,000 \mathrm{~km}^{3}$, which is equivalent to $10 \%$ of the annual runoff of the world's rivers. So far, $50 \%$ of the world's rivers has been controlled or altered by hydraulic projects before reaching the ocean [3]. Dam construction is a large part of human engineering infrastructure, which is the foundation for much of our daily lives. Damming rivers provides numerous conveniences for human societies. Dams and reservoirs can store water during raining seasons and later release it to provide a consistent discharge and maintain a sufficient flow throughout the year. However, while developing natural resources to provide better living conditions for humankind, we must also ensure that the associated environmental impacts are monitored and limited. 


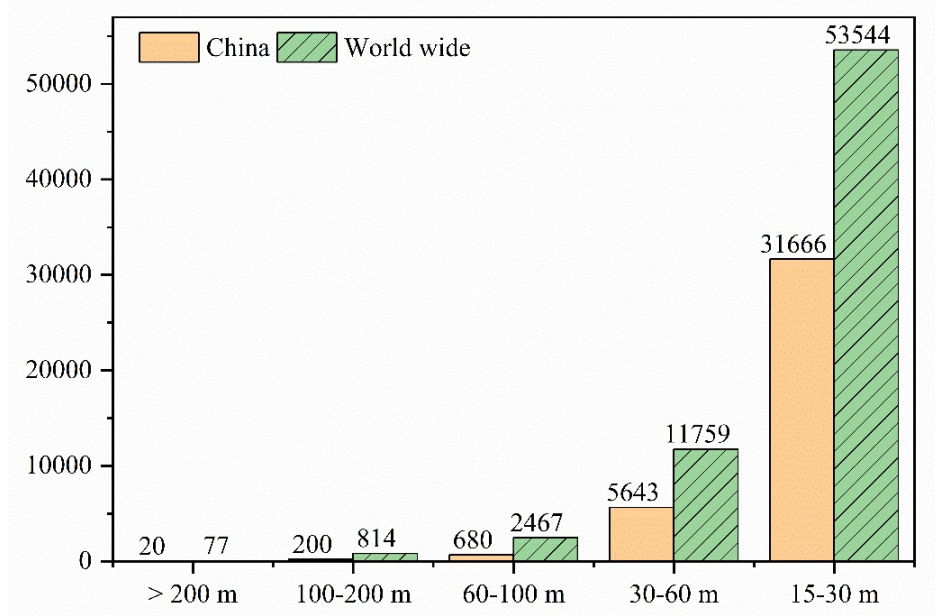

Figure 1. Number of registered dams in the world wide and China.

As a part of integrated watershed management, dam construction presents both opportunities and challenges. Dam closures convert dynamic rivers into static reservoirs, which effects the hydrography and morphological evolution of rivers by altering flow velocity, water quality, temperature, turbidity, particulate matter, and other physicochemical parameters of rivers $[2,4,5]$. Dams also result in major anthropogenic disturbances to the biogeochemical cycles of nutrients which affect downstream wetlands, estuaries, underwater deltas, and adjacent marine ecosystems [3,6]. In 1997, the International Commission on Large Dams published a document 'Position Paper on Dams and the Environment' which pointed out that improving environmental awareness was one of the most important developments at the end of the 20 th century. In 2016, Chinese government put forward the concept of "Great Protection of the Yangtze River" which made the ecological restoration of the Yangtze River Basin a priority concept that now pervades all related work.

There are 1811 large and medium-sized dam reservoirs on the Yangtze River. These dams have had a significant impact on the environment, but extensive and in-depth research is required to accurately characterize these effects. Unfortunately, because of the long distance covered by the Yangtze before it meets the ocean, and various other anthropogenic disturbances within the river basin, the roles of dams in marine ecosystems can easily be ignored. Long-term observation and research are necessary to assess the impacts of dams on ecosystems of estuarine and adjacent sea areas. This paper provides a review of recent studies on river damming and its impacts on ecosystems of estuarine and adjacent sea areas. This review aims to: (1) discuss changes in rivers by comparing periods before and after dam construction and relate these changes with sediment dynamics, nutrient fluxes, and estuarine ecosystems where rivers meet the sea and (2) identify the future directions and priorities for research in this field.

\section{Methodology}

The systematic bibliometric analyses were performed by ISI Web of Knowledge database [7,8]. The search string related to the study topic included "dam", "effect", "impact", "ecosystem", "estuary", "marine" and "sea". The subject areas were Agricultural and Biological Sciences, Environmental Science and Earth and Planetary Sciences. All retrieved files of journal papers, books, newspapers and conference articles (published between 2000 and 2021) were further evaluated and filtered: 1) continue search in the search to make sure all the search results related to the study topic; 2) all the dam effects focus on the estuary and nearby marine areas; 3 ) all the articles should be published. Finally, all the related files are classified into six categories: flow flux, sediment, geomorphology, nutrient, phytoplankton, fish. Not all the 235 relevant literatures retrieved were cited in this 
paper, because of the similar conclusions. The structured and systematic approach was performed in order to ensure the objectivity of conclusions $[9,10]$. In the end, future research directions were pointed out.

\section{Results}

The effects of dam construction on the environment of river estuary and its adjacent marine area was summarized with some examples. Effects of dams on ecosystem included regulating river flow, reducing sediment flux, changing water temperature of reservoir, erosion of estuary delta, altering the composition and distribution of nutrients, changing the structure and distribution of phytoplankton and habitat fragmentation in downstream rivers and their adjacent sea areas (Figure 2 and Table 1). 


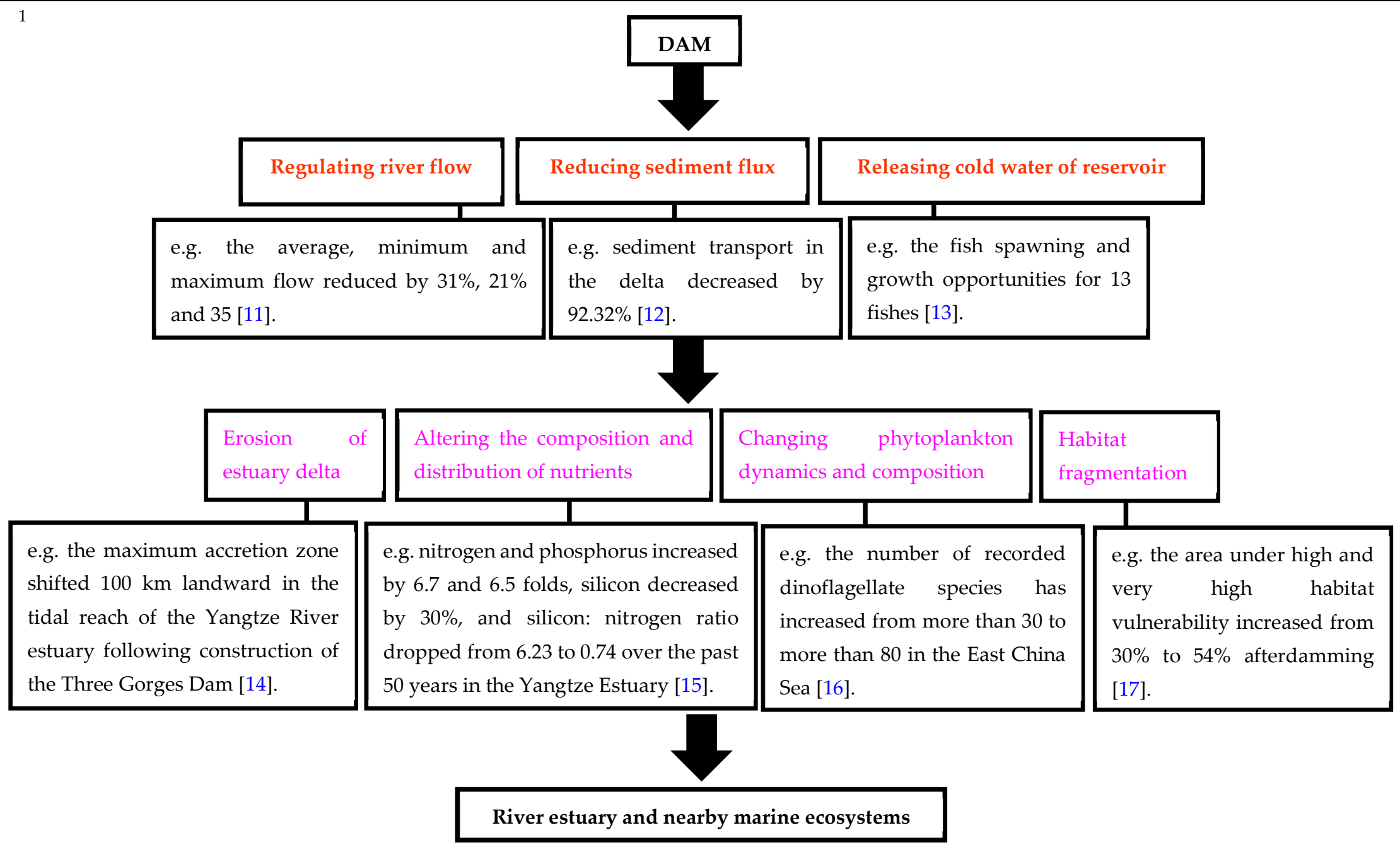

Figure 2. Effects of dam construction on ecosystem of river estuary and nearby marine area. 
3 Table 1. Studies about the effects of dam construction.

\begin{tabular}{l} 
Characteristics \\
\hline Reduces of river flow \\
Reduces of sediment transport \\
Changes sediment dynamics and geo- \\
morphic processes
\end{tabular}

nitrogen and phosphorus nutrient flux

silicon nutrient flux

\section{Effects on the downstream river and coastal water}

Reference

Would cause the flow reduce by $21 \%-90 \%$ in downstream area.

$[11,18,19]$

Would reduce the sediment transport by $75 \%-92 \%$ in downstream area.

$[12,20,21]$

Could cause retreatment of the estuarine turbidity maximum zone and lead to erosion $\quad[22-26]$

that degrades the underwater deltas in estuaries.

Could intercept about $42 \%-93 \%$ of river nutrients, especially phosphorus.

Have an effect on the river flow velocity, and less silicon is supplemented from the [31-35] continent and the amount of silicon land-sea fluxes decreased by $50 \%-80 \%$.

Nutrient ratios

Could reduce the silicon: nitrogen ratios sharply from 6.23 to 0.74 .

phytoplankton community

Have an impact on the phytoplankton composition and increase the outbreak num- $\quad[37,38]$ bers of harmful red tide.

Would decrease functional richness and the species diversity in downstream area.

Could provide positive and negative influences on the habitat suitability for birds.

[39-42]

bird

Would cause habitat fragmentation and even affect the fish populations, species and

[43-46]

fish sizes. 


\subsection{Effects of dam construction on sediment flux into the ocean}

A dam segments the river, changing it from a flowing whole to one impeded by a static reservoir that reduces river flow. The average, minimum and maximum flow reduced by 31\%, 21\% and 35\% in lower São Francisco Riverin after the construction of the Xingó reservoir [11]. After construction of the Farakka dam in India, the river flow into the downstream Bengal Bay showed a deficit of 75\% [19].

It has been reported that, in addition to impacting river flows, dams have important impacts on sediment dynamics and geomorphic processes [10,49-51]. Rivers are estimated to transport about $90 \%$ of all dissolved and particulate matter that is deposited in the ocean, and the total annual sediment transported by rivers is estimated at about 19 billion tons, representing a very important driver of hydrological changes and the morphological evolution of estuaries and adjacent sea areas [52]. Amenuvor et al. [12] studied the hydrology of Volta River before and after Akosombo Dam over the period from 1936 to 2018 using Landsat remote sensing images, and the results indicated that the establishment of the dam resulted in significant hydrological changes and altered the morphological evolution of the river. Their study showed that sediment transport and river flow in the delta decreased by $92.32 \%$ and $23.23 \%$, respectively. In major rivers of China, it has been found that the annual total sediment transport to coastal areas has decreased from 2.03 billion tons in 1955-1968 to 0.50 billion tons in 1997-2010 [20]. About 77\% sediment was trapped by the Three Gorges Reservoir [53]. Similarly, studies of sediment transport in Swiss rivers [21], Russian rivers [22], European rivers [23], North African rivers [24] and South East Asian rivers [25] have shown that anthropogenic disturbances in river basins (mainly dam and reservoir construction) are the main causes of reductions in sediment transport.

Dam construction will change the topography of the riverbank, increase the erosion of the downstream riverbed, and cause erosion that degrades the underwater deltas in estuaries [26,54,55]. For example, the maximum accretion zone shifted $100 \mathrm{~km}$ landward in the tidal reach of the Yangtze River estuary following construction of the Three Gorges Dam due to the decreasing sediment flux [14]. It has been reported that the estuarine turbidity maximum zone in Portugal moved 8-16 km upstream compared to previous records after the construction of the Alqueva Dam [47]. More attention should be given to the effects of dam construction on sediment flux into the ocean.

\subsection{Effects of dam construction on nutrient flux to the sea}

Artificial lakes formed by dam construction will affect the biogeochemical cycles of nutrients (carbon, nitrogen, phosphorus, silicon, etc.) in water. The nutrients in upstream reaches of a river are intercepted by the phytoplankton that flourish in the reservoirs. This removes nutrients from the water and has far-reaching ecological impact on the global biogeosphere. The effects of dams on riverine nutrient fluxes vary from one nutrient to another. About $42 \%-93 \%$ of river nutrients can be intercepted by reservoirs [27], especially phosphorus $(\mathrm{P})$, whose uptake in reservoirs ranges between $16 \%-98 \%[28,30]$. After the construction of the Three Gorges Dam, eutrophication in downstream reaches have been alleviated [56]. However, due to anthropogenic sources such as domestic sewage, industrial wastewater, and agricultural fertilization, the nitrogen inputs to coastal waters may increase by $20 \%$ and phosphorus inputs double in Indonesia by 2050, despite the dam nutrient retention [57].

Unlike other essential nutrients, silicon (Si) does not have downstream sources and is not resupplied to rivers after interception by dams [31,32]. Due to the effect of anthropogenic perturbations (mainly dam construction), the amounts of nitrogen $(\mathrm{N})$ and phosphorus $(\mathrm{P})$ have increased by 6.7 and 6.5 times, respectively, while the amount of silicon has decreased by $30 \%[15,30,58]$. In addition to nutrient retention, Si nutrient concentrations in downstream rivers and coastal marine areas can be reduced by other hydrological changes caused by dams. Under the influence of a dam, river flow velocity decreases, the 
erosion of river banks weakens, and the interaction between land and water is reduced. As a result, less $\mathrm{Si}$ is supplemented from the continent and the amount of silicon in the river decreases [33]. Humborg et al. [34] found that the major cause of the reduction in land-sea Si fluxes was dams. The dissolved silicate (DSi) yield of moderately dammed rivers was only $50 \%$ of the practically undammed river. It has also been reported that $80 \%$ of $\mathrm{Si}$ in the ocean has been imported from rivers [35]. Therefore, the global modification of riverine Si flux directly affects the distribution of ocean basin Si concentrations, especially for coastal marine areas.

High anthropogenic $\mathrm{N}$ and P nutrient loads reduce the Si: P and Si: N nutrient ratios $[15,36]$. Clearly, nutrient composition patterns have been fundamentally changed by dams as they alter the absolute nutrient fluxes and the nutrient ratios of riverine and coastal marine areas. These findings demonstrate that dams fundamentally alter water quality and nutrient supply in rivers.

\subsection{Effects of dam construction on ecosystems of the estuary and adjacent coastal area}

Estuaries are complex amalgams of various material systems, structural systems, functional systems, and energy systems. They are ecological transition zones and represent some of the most intense and complex land-sea interactions. Macronutrients are carried by rivers from land to estuaries, promoting the growth and reproduction of marine and saltwater tolerant organisms and maintaining the highly complex and variable ecosystems. The abundance of organic and inorganic elements in estuarine areas make them ideal for primary productivity, as is demonstrated by the plumes of highly productive areas fronting estuaries worldwide. As some of the highest productivity zones in the ocean, many famous fishing grounds are associated with estuaries, such as the Lvsi and Zhoushan fishing grounds in the Yangtze River estuary. However, estuaries and adjacent sea areas are frequently densely populated with developed agriculture and industry, which makes estuarine ecosystems highly impacted by human activities.

Downstream, estuarine, and adjacent marine ecosystems will all be affected by damming. Decreases in silicon concentrations and increases in nitrogen and phosphorus concentrations have been linked to changes in growth and species composition of phytoplankton communities, as well as increases in the frequency of harmful red tide outbreaks $[37,38]$. At present, Prorocentrum ranks as most frequent and disaster-associated red tide species, and has caused serious economic losses to fishing and aquaculture in the East China Sea [16]. Phytoplankton are important components of aquatic food webs, so changes in their abundance and composition can have effects on benthic animals, fishes, plants, and birds [39,59]. Worse still, marine products contaminated with algal toxins can cause illness or even death in humans if they are mistakenly consumed [60].

It is reported that, the species and richness of plants were significantly impacted by dam construction $[40,42,61]$. Most of studies in the research of dam effects focused on the plants in reservoir, downstream channel and lake. And the studies about the effects of dam on plants in coastal waters were insufficient. The water level and plant could be impacted by dam construction, and which would further effect the habitat suitability of birds [62-64]. A recent study claimed that the Three Gorge Dam artificially generated ecological water level and which provided benefits for birds [43]. Besides, effects of dams on flow changes created stable habitat for the American dippers [44]. However, some studies indicated that, dam construction would have negative influence on the habitat suitability for birds by destroying coastal wetlands $[45,46]$.

Habitat fragmentation could be impacted by damming. For instance, the area under high habitat vulnerability increased from $30 \%$ to $54 \%$ after damming wetland in Tangan river basin of India [17]. Damming can decimate local fishing industries by reducing the production of important commercial fish [7,13]. For example, dam construction caused a shift in the phytoplankton in the Guadiana estuary of Portugal change from diatoms to flagella and cyanobacteria. This shift caused a corresponding change in species of fish, from those that eat diatom phytoplankton (e.g., anchovies) to those that eat non-diatom 
phytoplankton, and the abundance of anchovy eggs decreased by $99.99 \%$ [47].Furthermore, the temperature decreased about $0.4^{\circ} \mathrm{C}$ after the completion of the Three Gorges Dam, which made the spawning time of the Chinese sturgeon change [61]. There is a similar case happened in Brazilian Amazon, where fish production and diversity were all impacted by dam construction [48].

\section{Management strategies}

Some scholars have explored how reservoir management can mitigate eutrophication in downstream rivers and adjacent sea areas. For example, targeted control of dam storage can increase $\mathrm{P}$ and $\mathrm{N}$ retention so as to reduce their downstream transfer [65]. At the same time, reasonable release of stored water during the growth of diatoms can avoid Si limitation in the diatom communities of estuaries and adjacent sea areas [66]. In addition, targeted control of sediment flushing operations and removing tributary low-head dams could decrease harm to ecosystems in downstream reaches [21,67]. The banning fishing activities of the Yangtze River and the removal of unnecessary dams (obsolete or small dams) are means of balancing social benefits and environmental health $[68,69]$. By exploring new reservoir management strategies and performing ecological environmental planning before dam constructions, we may be able to balance the social benefits and environmental consequences of dam construction. Overall, there is significant space for the continued development of dam management in the future.

\section{Conclusions}

Rivers carry water, sediment, and nutrients downstream to the ocean. Multipurpose dams are constructed in order to balance economic benefits and environmental costs. The environmental impacts of the dams should be considered before and after dam projects are undertaken. Due to the ubiquity of dams, the management of the water in rivers has become essential to nation building. Dams and reservoirs require us to apply integrated water management strategies as demands for hydroelectric, irrigation, recreation, domestic water supply, and environmental requirements all compete for a limited supply. Dams effect river flow, water temperature, sediment flux, erosion of estuary deltas, composition and distribution of nutrients, structure and distribution of phytoplankton communities, fish on ecosystems of downstream rivers and adjacent sea areas.

To study the influence of dam construction on the ecological environment, it is necessary to monitor and analyze the key ecological factors, so as to provide reliable data and a theoretical basis for subsequent assessments of dams. In order to balance the social benefits and ecological impacts of dam construction, new reservoir construction and management strategies should be explored. Mitigation policies made by government is a means of ecological rehabilitation. Under the guidance of sustainable development concepts, continuous improvement in technology and experience will provide scientific support for dam construction that effectively utilizes and protects the ecological environment.

The impacts of dam construction are not limited to its direct effects on downstream hydromorphology, ecosystems, and human life, but extends to the ecological environments of the estuary and its adjacent marine area. Balancing social and environmental benefits is an ongoing subject, so we suggest that: (1) more comprehensive and effective dam and reservoir management strategies should be explored in order to reduce effects of dam construction on ecosystem; (2) effects of dams on fish habitats and aquaculture in upper and downstream reaches need further study; and (3) the effects of dams on plants, fish, birds, and animals in downstream and adjacent marine waters be included in future studies to ensure a comprehensive assessment.

Author Contributions: Conceptualization, X.Z. and S.Y.; methodology, X.Z.; software, X.L.; investigation, C.F.; data curation, Y.W.; writing-original draft preparation, X.Z.; writing-review and editing, D.H.; visualization, C.F.; supervision, D.H.; project administration, S.Y.; funding acquisition, D.H. All authors have read and agreed to the published version of the manuscript. 
Funding: This study was financially supported by the National Key Research and Development Program of China (No. 2018YFC1407604).

Institutional Review Board Statement: Not applicable.

Informed Consent Statement: Not applicable.

Conflicts of Interest: The authors declare no conflicts of interest.

\section{References}

1. ICOLD (International Commission on Large Dams). World Register of Dams. 2021. Available online: http://www.icold-cigb.org (accessed 16 January 2022).

2. Zarfl, C.; Lumsdon, A.E.; Berlekamp, J.; Tydecks, L.; Tockner, K. A global boom in hydropower dam construction. Aquat. Sci. 2015, 77 (1), 161-170. https://doi.org/10.1007/s00027-014-0377-0.

3. Van Cappellen, P.; Maavara, T. Rivers in the Anthropocene: Global scale modifications of riverine nutrient fluxes by damming. Ecohydrol. Hydrobiol. 2016, 16 (2), 106-111. https://doi.org/10.1016/j.ecohyd.2016.04.001.

4. Best, J. Anthropogenic stresses on the world's big rivers. Nat. Geosci. 2019, 12, 7-21. https://doi.org/10.1038/s41561-018-0262-x.

5. Pearson, A.J.; Pizzuto, J.E.; Vargas, R. Influence of run of river dams on floodplain sediments and carbon dynamics. Geoderma. 2016, 272, 51-63. https://doi.org/10.1016/j.geoderma.2016.02.029.

6. Donald, D.B.; Parker, B.R.; Davies, J.M.; Leavitt, P.R. Nutrient sequestration in the Lake Winnipeg watershed. J. Great Lakes Res. 2015, 41 (2), 630-642. https://doi.org/10.1016/j.jglr.2015.03.007.

7. Wu, H.; Chen, J.; Xu, J.; Zeng, G.; Sang, L.; Liu, Q.; Yin, Z.; Dai, J.; Yin, D.; Liang, J.; Ye, S. Effects of dam construction on biodiversity: A review. J. Cleaner Prod. 2019, 221, 480-489. https://doi.org/10.1016/j.jclepro.2019.03.001.

8. Zhang, Y.; Huang, K.; Yu, Y.; Yang, B. Mapping of water footprint research: A bibliometric analysis during 2006-2015. J. Cleaner Prod. 2017, 149, 70-79. https://doi.org/10.1016/j.jclepro.2017.02.067.

9. Rodrigues, M.; Mendes, L. Mapping of the literature on social responsibility in the mining industry: A systematic literature review. J. Cleaner Prod. 2018, 181, 88-101. https://doi.org/10.1016/j.jclepro.2018.01.163.

10. Chong, X.; Vericat, D.; Batalla, R.J.; Teo, F.Y.; Lee, K.S.P.; Gibbins, C.N. A review of the impacts of dams on the hydromorphology of tropical rivers. Sci. Total Environ. 2021, 794, 148686. https://doi.org/10.1016/j.scitotenv.2021.148686.

11. Nascimento do Vasco, A.; de Oliveira Aguiar Netto, A.; Gonzaga da Silva, M. The influence of dams on ecohydrological conditions in the São Francisco River Basin. Brazil. Ecohydrol. Hydrobiol. 2019, 19, 556-565. https://doi.org/10.1016/j.ecohyd.2019.03.004.

12. Amenuvor, M.; Gao, W.; Li, D.; Shao, D. Effects of dam regulation on the hydrological alteration and morphological evolution of the Volta River Delta. Water 2020, 12 (3), 646-658. https://doi.org/10.3390/w12030646.

13. Cheng, F; Li, W.; Castello, L.; Murphy, B.R.; Xie, S. Potential effects of dam cascade on fish: lessons from the Yangtze River. Rev. Fish Biol. Fisheries 2015, 25, 569-585. https://doi.org/10.1007/s11160-015-9395-9.

14. Mei, X.; Dai, Z.; Darby, S.E.; Zhang, M.; Cai, H.; Wang, J.; Wei, W. Landward shifts of the maximum accretion zone in the tidal reach of the Changiang estuary following construction of the Three Gorges Dam. J. Hydrol. 2021, 592, 125789. https://doi.org/10.1016/j.jhydrol.2020.125789.

15. Dai, Z.; Du, J.; Zhang, X.; Su, N.; Li, J. Variation of riverine material loads and environmental consequences on the Changjiang (Yangtze) estuary in recent decades (1955-2008). Environ. Sci. Technol. 2011, 45 (1), 223-227. https://doi.org/10.1021/es103026a.

16. Chen, N.; Chen, Y. Advances in the study of biodiversity of phytoplankton and red ride species in China (II): The East China Sea. Oceanol. Limnol. Sin. 2021, 52 (2), 363-418 (in Chinese). https://doi.org/10.11693/hyhz20200900264.

17. Talukdar, S.; Pal, S.; Chakraborty, A.; Mahato, S. Damming effects on trophic and habitat state of riparian wetlands and their spatial relationship. Ecol. Indic. 2020, 118, 106757. https://doi.org/10.1016/j.ecolind.2020.106757.

18. Sakho, I.; Dupont, J.P.; Cisse, M.T.; Janyani, S.E.; Loum, S. Hydrological responses to rainfall variability and dam construction: a case study of the upper Senegal River basin. Environ. Earth Sci. 2017, 76 (6), 1-19. https://doi.org/10.1007/s12665-017-6570-4.

19. Grumbine, R.E.; Pandit, M.K. Threats from India's Himalaya Dams. Science 2013, 339, 6115. https://doi.org/10.1126/science.1227211.

20. Liu, C.; He, Y.; Li, Z.; Chen, J.; Li, Z. Key drivers of changes in the sediment loads of Chinese rivers discharging to the oceans. Int. J. Sediment Res. 2021, 36 (6), 747-755. https://doi.org/10.1016/j.ijsrc.2020.05.005.

21. Cattanéo, F.; Guillard, J.; Diouf, S.; O'Rourke, J.; Grimardias, D. Mitigation of ecological impacts on fish of large reservoir sediment management through controlled flushing-The case of the Verbois dam (Rhône River, Switzerland). Sci. Total Environ. 2021, 756, 144053. https://doi.org/10.1016/j.scitotenv.2020.144053.

22. Bobrovitskaya, N.N.; Kokorev, A.V.; Lemeshko, N.A. Regional patterns in recent trends in sediment yields of Eurasian and Siberian rivers. Global Planet Change 2003, 39 127-146. https://doi.org/10.1016/S0921-8181(03)00021-3.

23. Duarte, G.; Segurado, P.; Haidvogl, G.; Pont, D.; Ferreira, M.T.; Branco, P. Damn those damn dams: Fluvial longitudinal connectivity impairment for European diadromous fish throughout the 20th century. Sci. Total Environ. 2021, 761, 143293. https://doi.org/10.1016/j.scitotenv.2020.143293.

24. El Aoula, R.; Mhammdi, N.; Dezileau, L.; Mahe, G.; Kolker, A.S. Fluvial sediment transport degradation after dam construction in North Africa. J. Afr. Earth Sci. 2021, 182 104255. https://doi.org/10.1016/j.jafrearsci.2021.104255. 
25. Bussi, G.; Darby, S.E.; Whitehead, P.G.; Jin, L.; Dadson, S.J.; Voepel, H.E.; Vasilopoulos, G.; Hackney, C.R.; Hutton, C.; Berchoux, T.; Parsons, D.R.; Nicholas, A. Impact of dams and climate change on suspended sediment flux to the Mekong delta. Sci. Total Environ. 2021, 755, 142468. https://doi.org/10.1016/j.scitotenv.2020.142468.

26. Besset, M.; Anthony, E.J.; Bouchette, F. Multi-decadal variations in delta shorelines and their relationship to river sediment supply: An assessment and review. Earth-Sci. Rev. 2019, 193, 199-219. https://doi.org/10.1016/j.earscirev.2019.04.018.

27. Ounissi, M.; Bouchareb, N. Nutrient distribution and fluxes from three Mediterranean coastal rivers (NE Algeria) under large damming. C. R. Geosci. 2013, 345 (2), 81-92. https://doi.org/10.1016/j.crte.2013.02.002.

28. North, R.; Johansson, J.; Vandergucht, D.; Doig, L.; Liber, K.; Lindenschmidt, K.; Baulch, H.; Hudson, J. Evidence for internal phosphorus loading in a large prairie reservoir (Lake Diefenbaker, Saskatchewan). J. Great Lakes Res. 2015, 41 (Suppl 2), 91-99. https://doi.org/10.1016/j.jglr.2015.07.003.

29. Ding, S.; Chen, P.; Liu, S.; Zhang, G.; Zhang, J.; Dan, S.F. Nutrient dynamics in the Changjiang and retention effect in the Three Gorges Reservoir. J. Hydrol. 2019, 574, 96-109. https://doi.org/10.1016/j.jhydrol.2019.04.034.

30. Ni, Z.; Wang, S.; Wu, Y.; Liu, X.; Lin, R.; Liu, Z. Influence of exposure time on phosphorus composition and bioavailability in wetland sediments from Poyang lake, since the operation of the Three Gorges Dam. Environ. Pollut. 2020, $263,114591$. https://doi.org/10.1016/j.envpol.2020.114591.

31. Maavara, T.; Dürr, H.H.; Van Cappellen, P. Worldwide retention of nutrient silicon by river damming: From sparse data set to global estimate. Global Biogeochem. Cycles 2014, 28 (8), 842-855. https://doi.org/10.1002/2014GB004875.

32. Conceição, L.P.; de Jesus Affe, H.M.; da Silva, D.M.L.; de Castro Nunes, J.M. Spatio-temporal variation of the phytoplankton community in a tropical estuarine gradient, under the influence of river damming. Reg. Stud. Mar. Sci. 2012, $43,101642$. https://doi.org/10.1016/j.rsma.2021.101642.

33. Maavara, T.; Hood, J.L.A.; North, R.L.; Doig, L.E.; Parsons, C.T.; Johansson, J.; Liber, K.; Hudson, J.J.; Lucas, B.T.; Vandergucht, D.M.; Van Cappellen, P. Reactive silicon dynamics in a large prairie reservoir (Lake Diefenbaker, Saskatchewan). J. Great Lakes Res. 2015, 41 (Suppl 2), 100-109. https://doi.org/10.1016/j.jglr.2015.04.003.

34. Humborg, C.; Pastuszak, M.; Aigars, J.; Siegmund, H.; Mörth, C.M.; Ittekkot, V. Decreased silica land-sea fluxes through damming in the Baltic Sea catchment-significance of particle trapping and hydrological alterations. Biogeochemistry 2006, 77, 265281. https://doi.org/10.1007/s10533-005-1533-3.

35. Conley, D.J.; Humborg, C.; Smedberg, E.; Rahm, L.; Papush, L.; Danielsson, A.; Clarke, A.; Pastuszak, M.; Aigars, J.; Ciuffa, D.; Mörth, C.M. Past, present and future state of the biogeochemical Si cycle in the Baltic Sea. J. Marine Syst. 2008, 73 (3-4), $338-346$. https://doi.org/10.1016/j.jmarsys.2007.10.016.

36. Liang, C.; Xian, W. Changjiang nutrient distribution and transportation and their impacts on the estuary. Cont. Shelf Res. 2018, 165, 137-145. https://doi.org/10.1016/j.csr.2018.05.001.

37. Friedl, G.; Wuest, A. Disrupting biogeochemical cycles-Consequences of damming. Aquat. Sci. 2002, 64 (1), 55-65. https://doi.org/10.1007/s00027-002-8054-0.

38. Lum, W.M.; Benico, G.; Doan-Nhu, H.; Furio, E.; Leaw, C.P.; Leong, S.C.Y.; Lim, P.T.; Lim, W.A.; Lirdwitayaprasit, T.; Lu, S.; Muawanah, N.V.; Orlova, T.Y.; Rachman, A. Sakamoto, S. Takahashi, K. Teng, S.T.; Thoha, H.; Wang, P.; Yñiguez, A.T.; Wakita, K.; Iwataki, M. The harmful raphidophyte Chattonella (Raphidophyceae) in Western Pacific: Its red tides and associated fisheries damage over the past 50 years (1969-2019). Harmful Algae 2021, 107, 102070. https://doi.org/10.1016/J.HAL.2021.102070.

39. Tumer, R.E. Element ratios and aquatic food webs. Estuaries Coasts 2002, 25 (4), 694-703. https://doi.org/10.1007/BF02804900.

40. Bombino, G.; Boix-Fayos, C.; Gurnell, A.M.; Tamburino, V.; Zema, D.A.; Zimbone, S.M. Check dam influence on vegetation species diversity in mountain torrents of the Mediterranean environment. Ecohydrology 2014, 7 (2), 678e691. https://doi.org/10.1002/eco.1389.

41. Wang, Q.; Yuan, X.; Willison, J.H.M.; Zhang, Y.; Liu, H. Diversity and above-ground biomass patterns of vascular flora induced by flooding in the drawdown area of China's Three Gorges Reservoir. PLOS ONE 2016, 11(1), e0147452. https://doi.org/10.1371/journal.pone.0147452.

42. Shi, L.; Wang, Y.; Jia, Y.; Lu, C.; Lei, G.; Wen, L. Vegetation cover dynamics and resilience to climatic and hydrological disturbances in seasonal floodplain: the effects of hydrological connectivity. Front Plant Sci. 2017, 8, 2196. https://10.3389/fpls.2017.02196.

43. Zhu, Y.; Wang, H.; Guo, W. The impacts of water level fluctuations of East Dongting Lake on habitat suitability of migratory birds. Ecol. Indic. 2021, 132, 108277. https://doi.org/10.1016/j.ecolind.2021.108277.

44. Silverthorn, V.M.; Bishop, C.A.; Elliott, J.E.; Morrissey, C.A. An assessment of run-of-river hydroelectric dams on mountain stream ecosystems using the American dipper as an avian indicator. Ecol. Indic. 2018, 93, 942-951. https://doi.org/10.1016/j.ecolind.2018.05.086.

45. Wu, H.; Dai, J.; Sun, S.; Du, C.; Long, Y.; Chen, H.; Yu, G.; Ye, S.; Chen, J. Responses of habitat suitability for migratory birds to increased water level during middle of dry season in the two largest freshwater lake wetlands of China. Ecol. Indic. 2021, 121, 107065. https://doi.org/10.1016/j.ecolind.2020.107065.

46. Wu, H.; Chen, J.; Zeng, G.; Xu, J.; Sang, L.; Liu, Q.; Dai, J.; Xiong, W.; Yuan, Z.; Wang, Y.; Ye, S. Effects of early dry season on habitat suitability for migratory birds in China's two largest freshwater lake wetlands after the impoundment of Three Gorges Dam. J. Environ. Informatics 2019, 36 (2), 89-92 https://doi.org/10.3808/jei.201900411.

47. Morais, P.; Chicharo, M.A.; Chicharo, L. Changes in a temperate estuary during the filling of the biggest European dam. Sci. Total Environ. 2009, 407 (7), 2245-2259. https://doi.org/10.1016/j.scitotenv.2008.11.037. 
48. Sousa, R.G.C.; de Freitas, H.C.P.; Zacardi, D.M.; Faria-Junior, C.H. Effects of river dams on the fish guilds in the northwest region of the Brazilian Amazon. Fish Res. 2021, 243, 106091. https://doi.org/10.1016/j.fishres.2021.106091.

49. Manh, N.V.; Dung, N.V.; Hung, N.N.; Kummu, M.; Merz, B.; Apel, H. Future sediment dynamics in the Mekong Delta floodplains: Impacts of hydropower development, climate change and sea level rise. Global Planet Change 2015, 127, 22-23. https://doi.org/10.1016/j.gloplacha.2015.01.001.

50. Kondlf, G.M.; Rubin, Z.K.; Minear, J.T. Dams on the Mekong: Cumulative sediment starvation. Water Resour. Res. 2014, 50, 51585169. https://doi.org/10.1002/2013WR014651.

51. Ge, J.; Zhang, J.; Chen, C.; Ding, P. Impacts of fluvial flood on physical and biogeochemical environments in estuary-shelf continuum in the East China Sea. J. Hydrol. 2021, 598, 126441. https://doi.org/10.1016/j.jhydrol.2021.126441.

52. Velbel, M.A. Material fluxes on the surface of the earth: Board on Earth Sciences and Resources, Commission on Geosciences, Environment and Resources, National Research Council, 1994. National Academy of Sciences, National Academy Press, Washington, DC, 170 pp. Earth-Sci. Rev. 1996, 41 (3-4), 211-212. https://doi.org/10.1016/S0012-8252(96)00025-6.

53. Li, S.; Xu, Y.; Ni, M. Changes in sediment, nutrients and major ions in the world largest reservoir: Effects of damming and reservoir operation. J. Cleaner Prod. 2021, 318, 128601. https://doi.org/10.1016/j.jclepro.2021.128601.

54. Wu, X.; Bi, N.; Xu, J.; Nittrouer, J.A.; Yang, Z.; Saito, Y.; Wang, H. Stepwise morphological evolution of the active Yellow River (Huanghe) delta lobe (1976-2013): Dominant roles of riverine discharge and sediment grain size. Geomorphology 2017, 292, 115127. https://doi.org/10.1016/j.geomorph.2017.04.042.

55. Lyu, Y.; Fagherazzi, S.; Tan, G.; Zheng, S.; Feng, Z.; Han, S.; Shu, C. Hydrodynamic and geomorphic adjustments of channel bars in the Yichang- Chenglingi Reach of the Middle Yangtze River in response to the Three Gorges Dam operation. Catena 2020, 193, 104628. https://doi.org/10.1016/j.catena.2020.104628.

56. Wang, H.; Yan, H.; Zhou, F.; Li, B.; Zhuang, W.; Shen, Y. Changes in nutrient transport from the Yangtze River to the East China Sea linked to the Three-Gorges Dam and water transfer project. Environ. Pollut. 2020, 256, 113376. https://doi.org/10.1016/j.envpol.2019.113376.

57. Suwarno, D.; Löhr, A.; Kroeze, C.; Widianarko, B.; Strokal, M. The effects of dams in rivers on N and P export to the coastal waters in Indonesia in the future. Sustain. Water Qual. Ecol. 2014, 3-4, 55-66. https://doi.org/10.1016/j.swaqe.2014.11.005.

58. Grabb, K.C.; Ding, S.; Ning, X.; Liu, S.M.; Qian, B. Characterizing the impact of Three Gorges Dam on the Changjiang (Yangtze River): A story of nitrogen biogeochemical cycling through the lens of nitrogen stable isotopes. Environ. Res. 2021, 195, 110759. https://doi.org/10.1016/j.envres.2021.110759.

59. Senneville, S.; Schloss, I.R.; St-Onge Drouin, S.; Bélanger, S.; Winkler, G.; Dumont, D.; Johnston, P.; St-Onge, I. Moderate effect of damming the Romaine River (Quebec, Canada) on coastal plankton dynamics. Estuarine Coastal Shelf Sci. 2018, $203,29-43$. https://doi.org/10.1016/j.ecss.2018.02.006.

60. Lin, S.; Ji, N.; Luo, H. Recent progress in marine harmful algal bloom research. Oceanol Limnol. Sin. 2019 , 50 (3), $495-510$. https://doi.org/10.11693/hyhz20180800191.

61. Wang, H.; Yuan, W.; Zeng, Y.; Liang, D.; Zhang, X.; Li, B.; Xia, Y.; Wu, S. Three Gorges Dam alters the footprint of particulate heavy metals in the Yangtze Estuary. Sci. Total Environ. 2022, 803, 150111. https://doi.org/10.1016/j.scitotenv.2021.150111.

62. Beja, P.; Santos, C.D.; Santana, J.; Ramos-Pereira, M.J.; Marques, J.T.; Queiroz, H.L.; Palmeirim, J.M. Seasonal patterns of spatial variation in understory bird assemblages across a mosaic of flooded and unflooded Amazonian forests. Biodivers Conserv. 2010, 19, 129-152. https://doi.org/10.1007/s10531-009-9711-6.

63. Wang, Y.; Jia, Y.; Guan, L.; Lu, C.; Lei, G.; Wen, L.; Liu, G. Optimising hydrological conditions to sustain wintering waterbird populations in Poyang Lake National Natural Reserve: implications for dam operations. Freshw. Biol. 2013, 58 (11), $2366 \mathrm{e} 2379$. https://doi.org/10.1111/fwb.12216.

64. Yao, S.; Li, X.; Liu, C.; Zhang, J.; Li, Y.; Gan, T.; Liu, B.; Kuang, W. New assessment indicator of habitat suitability for migratory bird in wetland based on hydrodynamic model and vegetation growth threshold. Ecol. Indic. 2020, 117, 106556. https://doi.org/10.1016/j.ecolind.2020.106556.

65. Visser, P.M.; Ibelings, B.W.; Bormans, M.; Huisman, J. Artificial mixing to control cyanobacterial blooms: a review. Aquat. Ecol. 2016, 50 (3), 423-441. https://doi.org/10.1007/s10452-015-9537-0.

66. Garnier, J.; Beusen, A.; Thieu, V.; Billen, G.; Bouwman, L. N:P:Si nutrient export ratios and ecologicalconsequences in coastal seas evaluated by the ICEP approach. Global Biogeochem Cycles 2010, 24, GB0A05. https://doi.org/10.1029/2009GB003583.

67. Tang, L.; Mo, K.; Zhang, J.; Wang, J.; Chen, Q.; He, S.; Zhu, C.; Lin, Y. Removing tributary low-head dams can compensate for fish habitat losses in dammed rivers. J. Hydrol. 2021, 598, 126204. https://doi.org/10.1016/j.jhydrol.2021.126204.

68. Xu, X.; Yang, G.; Tan, Y.; Liu, J.; Zhang, S.; Bryan, B. Unravelling the effects of large-scale ecological programs on ecological rehabilitation of China's Three Gorges Dam. J. Cleaner Prod. 2020, 256, 120446. https://doi.org/10.1016/j.jclepro.2020.120446.

69. Tonra, M.C.; Fradkin, K.S.; Morley, S.A.; Duda, J.J.; Marra, P.P. The rapid return of marine-derived nutrients to a freshwater food web following dam removal. Biol. Conserv. 2015, 192, 130-134. https://doi.org/10.1016/j.biocon.2015.09.009. 